\title{
PENGARUH MOTIVASI, LINGKUNGAN KERJA DAN KOMPETENSI TERHADAP KINERJA KARYAWAN PADA PT. ANGKASA PURA II (PERSERO) KANTOR CABANG KUALANAMU
}

\author{
${ }^{1}$ Bambang Nugroho, ${ }^{2}$ Imarlia Ginting, ${ }^{3}$ Sri Wanti Nasution, ${ }^{4}$ Eva Susanti, ${ }^{5}$ Ummy Syahti \\ $1,2,3,4,5$ Universitas Islam Sumatera Utara \\ I'bambang.nugroho@gmail.com, ${ }^{2}$ irmalia.ginting@gmail.com, ${ }^{3}$ sriwanti.nst@gmail.com, ${ }^{4}$ eva.susanti@gmail.com, \\ 5 ummy.syahti@gmail.com
}

\begin{abstract}
Optimal performance on each employee will affect the company's activities where it is expected by the company that employees must always improve their performance for the benefit and benefit of the company. Many factors can determine the ups and downs of the performance of employees in each company. These factors include the things that influence motivation of employees, the existence of a comfortable work environment and training related to employee competence. The purpose of this study was to determine the effect of motivation, work environment and competence on employee performance at PT. Angkasa Pura II (Persero) Kualanamu Branch Office. This study uses an associative approach, namely research conducted to determine the effect or relationship between the independent variables with the dependent variable. The results showed that partial motivation did not have a significant effect on employee performance. Partially work environment has a significant effect on employee performance. Partially competence have a significant effect on employee performance. Simultaneously motivation, work environment and competence have a significant effect on performance. Obtained the results of the coefficient of determination is worth 0.825 or $82.5 \%$ meaning that around $82.5 \%$ of the performance variable can be explained by the motivation variable, work environment and competence. Or it can be said that the contribution of motivation, work environment and competence to employee performance at PT. Angkasa Pura II (Persero) Kualanamu Branch Office is $82.5 \%$. The remaining $17.5 \%$ is influenced by variables not examined in this study.
\end{abstract}

Keywords: Motivation, Work Environment, Competence and Performance

\begin{abstract}
ABSTRAK : Kinerja yang optimal pada setiap karyawan akan mempengaruhi aktivitas kegiatan perusahaan dimana diharapkan oleh perusahaan bahwa karyawan harus selalu meningkatkan kinerjanya demi kepentingan dan keuntungan perusahaan. Banyak faktor yang dapat menentukan naik turunnya kinerja karyawan di setiap perusahaan. Faktor-faktor tersebut diantaranya adalah hal-hal yang mempengaruhi motivasi kerja karyawan, adanya lingkungan kerja yang nyaman dan adanya pelatihan terkait kompetensi karyawan. Tujuan dari penelitian ini adalah untuk mengetahui pengaruh motivasi, lingkungan kerja dan kompetensi terhadap kinerja karyawan pada PT. Angkasa Pura II (Persero) Kantor Cabang Kualanamu. Penelitian ini menggunakan pendekatan asosiatif, yaitu penelitian yang dilakukan untuk mengetahui pengaruh atau hubungan antara variabel bebas dengan variabel terikat. Hasil penelitian menunjukkan bahwa secara parsial motivasi tidak memiliki pengaruh yang signifikan terhadap kinerja karyawan. Secara parsial lingkungan kerja memiliki pengaruh yang signifikan terhadap kinerja karyawan. Secara parsial kompetensi memiliki pengaruh yang signifikan terhadap kinerja karyawan. Secara simultan motivasi, lingkungan kerja dan kompetensi memiliki pengaruh yang signifikan terhadap kinerja. Diperoleh hasil koefisien determinasi bernilai 0.825 atau $82.5 \%$ artinya menunjukkan bahwa sekitar $82.5 \%$ variabel kinerja dapat dijelaskan oleh variabel motivasi, lingkungan kerja dan kompetensi. Atau dapat dikatakan bahwa kontribusi motivasi, lingkungan kerja dan kompetensi terhadap kinerja karyawan pada PT. Angkasa Pura II (Persero) Kantor Cabang Kualanamu adalah sebesar $82.5 \%$. Sisanya sebesar $17.5 \%$ dipengaruhi oleh variabel yang tidak diteliti dalam penelitian ini.
\end{abstract}

Kata Kunci : Motivasi, Lingkungan Kerja, Kompetensi dan Kinerja 


\section{Pendahuluan}

Dalam menjalankan kegiatan usahanya, perusahaan tentunya membutuhkan sumber daya salah satunya yaitu karyawan. Karyawan merupakan sumber daya yang penting bagi perusahaan karena memiliki bakat, tenaga dan kreativitas yang sangat dibutuhkan oleh perusahaan untuk mencapai tujuannya. Tanpa mesin canggih, perusahaan dapat terus beroperasi secara manual, akan tetapi tanpa karyawan, perusahaan tidak akan dapat berjalan sama sekali. Dengan demikian karyawan merupakan faktor kunci yang harus dipertahankan pada suatu perusahan. Secara umum karyawan sangatlah dibutuhkan oleh setiap perusahaan atau lembaga, karena tanpa karyawan pekerjaan tidak bisa terselesaikan dan tentunya perusahaan tidak dapat beroperasi. Itulah mengapa setiap perusahaan membutuhkan karyawan untuk setiap operasionalnya.

Adanya karyawan pada suatu perusahaan tanpa dibarengi dengan kinerja yang baik maka perusahaan tersebut akan mengalami keterlambatan dalam berkembang. Kinerja adalah hasil kerja secara kualitas dan kuantitas yang dicapai oleh seorang karyawan dalam melaksanakan tugasnya sesuai dengan tanggung jawab yang diberikan kepadanya Maka tidak heran apabila masing-masing perusahaan mendambakan karyawan dengan kinerja yang maksimal. Pentingnya peningkatan kinerja pada setiap karyawan akan mempengaruhi aktivitas kegiatan perusahaan dimana diharapkan oleh perusahaan bahwa karyawan harus selalu meningkatkan kinerjanya demi kepentingan dan keuntungan perusahaan. Hal ini sejalan dengan hasil penelitian Bukhari dan Sjahril Effendi Pasaribu (2019) yang menyimpulkan bahwa faktor yang dapat mempengaruhi kinerja karyawan adalah motivasi, lingkungan kerja dan kompetensi.

Hal tersebut juga terjadi di perusahaan PT. Angkasa Pura II (Persero) Kantor Cabang Kualanamu. PT. Angkasa Pura II merupakan salah satu perusahaan dibawah naungan Kementerian Badan Usaha Milik Negara yang bergerak di bidang jasa penerbangan. Memiliki motivasi kerja yang tinggi, lingkungan kerja yang optimal dan adanya kompetensi yang memadai sangat mempengaruhi kinerja karyawan. Hal diatas diharapkan akan membentuk seorang karyawan profesional dan dapat meningkatkan produktifitas perusahaan tersebut.
Namun berdasarkan awal riset di perusahaan PT. Angkasa Pura II (Persero) Kantor Cabang Kualanamu, pernyataan pada paragraf di atas tidak sesuai. Hal tersebut ditandai dengan adanya beberapa fenomena yang tidak sejalan dengan pernyataan tersebut.

Untuk mencapai motivasi kerja yang berkelanjutan pada karyawan, perusahaan telah melakukan berbagai macam cara dengan memberikan kepada karyawan gaji, tunjangan, kesempatan dalam pengembangan karir, pelatihan dan fasilitas sudah sesuai standar yang ditetapkan pemerintah. Seperti contoh, gaji yang diberikan sudah melebihi batas minimum UMK (Upah Minimum Kabupaten/Kota) Kabupaten Deli Serdang. Sesuai peraturan pemerintah provinsi Sumatera Utara dalam Surat Keputusan Gubernur Sumatera Utara Nomor 188.44/674/KPTS/2019 dinyatakan bahwa UMK 2020 Kabupaten Deli Serdang sebesar Rp. 3.118.592. Fasilitas kerja dan fasilitas kesehatan juga sudah dipenuhi oleh perusahaan kepada karyawan. Namun hal tersebut tidak serta merta meningkatkan motivasi kinerja karyawan. Hal tersebut ditandai dengan adanya karyawan yang bekerja hanya untuk memenuhi jam kerja tanpa memaksimalkan waktu kerjanya dengan melaksanakan program kerja yang telah ditentukan, sedangkan perusahaan mengharapkan kinerja yang lebih dari hal tersebut seperti kemampuan berinovasi, berkolaborasi dengan unit lain dan loyal terhadap perusahaan.

Selain fenomena diatas, fenomena lain berdasarkan survey di lokasi penelitian terlihat bahwa ada beberapa ruang kerja yang kurang optimal seperti plafon terdapat rembesan air, ruangan yang terkesan kusam dikarenakan sudah memudarnya cat pada dinding ruang kerja. Sirkulasi udara yang kurang baik, bangunan perkantoran memiliki udara yang mengandung lebih banyak zat kimia dan biologi daripada di luar ruangan. Hal ini disebabkan karena kurang terpeliharanya sistem sirkulasi dalam kantor dan terjadi kontaminasi udara yang dihasilkan dari penuaan gedung dan alat kantor. Ruang kerja yang sempit dimana tidak adanya sekat antara alat kerja dengan ruang kerja. Ditambah dengan kurangnya contoh teladan pada karyawan dengan grade/ level satu tingkat diatas seperti kurang aktif mengarahkan anggota dibawahnya, hanya menyuruh saja tanpa ikut bekerja dilapangan dan kurangnya komunikasi antara satu dengan yang lainnya. 
Hal tersebut menurunkan kinerja karyawan dikarenakan mereka merasa lingkungan kerja tempat mereka bekerja kurang nyaman.

Begitu juga halnya dengan fenomena kompetensi. Untuk meningkatkan kompetensi personil, perusahaan telah memberikan diklat keseluruh personil karyawan teknik agar mereka mampu merawat peralatan yang ada di Bandar Udara. Selain itu perusahan telah melakukan Pelatihan diluar bidang kerjanya seperti pengadaan barang dan jasa. Hal tersebut tidak serta merta meningkatkan kinerja karyawan. Hal tersebut ditandai dengan kurangnya kemampuan karyawan dalam menganalisa permasalahan pada suatu peralatan apabila terjadi kerusakan yang mengakibatkan terputusnya operasional dari alat tersebut, sedangkan PT Angkasa pura II (persero) core bisnisnya adalah menjual jasa dan alat tersebut merupakan salah satu jasa pelayanan untuk pengguna jasa Bandar Udara.

Banyak faktor-faktor yang dapat mempengaruhi kinerja karyawan di setiap perusahaan. Faktor-faktor tersebut harus selalu diperhatikan oleh perusahaan agar tujuan dari perusahaan dapat terwujud. Sudah pasti setiap perusahaan menginginkan kegiatan operasionalnya berjalan dengan baik dan mendapatkan hasil atau keuntungan yang meningkat setiap tahun berjalan. Ada tiga faktor yang mempengaruhi kinerja karyawan menurut Payaman J Simanjuntak (2005)

Faktor pertama yaitu faktor individu, faktor individu adalah kemampuan dan keterampilan melakukan kerja. Kompetensi seseorang dipengaruhi oleh beberapa faktor yang dapat dikelompokan dalam dua golongan, yaitu kemampuan dan keteerampilan kerjaserta motivasi dan eyos kerja.

Faktor kedua yaitu faktor dukungan organisasi. Dalam melaksanakan tugasnya, karyawan memerlukan dukungan organisasi tempat karyawan bekerja.Dukungan tersebut adalah dalam bentuk pengorganisasian, penyediaan sarana dan prasarana kerja, kenyamanan lingkungan kerja, serta kondisi dan syarat-syarat kerja. Pengorganisasian dimaksudkan untuk memberikan kejelasan bagi setiap orang tentang sasaran yang harus dicapai dan apa yang harus dilakukan untuk mencapai sasaran tersebut. Setiap orang perlu memiliki dan memahami uraian jabatan dan tugas yang jelas.

Faktor ketiga yaitu dukungan manajemen, kinerja perusahaan dan kinerja setiap orang juga sangat tergantung pada kemampuan manajerial para manajemen atau pimpinan, baik denagan membangun sistem kerja dan hubungan industrial yang aman dan harmonis, maupun dengan mengembangan kompetensi karyawan, demikian juga dengan menumbuhkan motivasi seluruh karyawan untuk bekerja secara optimal.

Variabel motivasi, lingkungan kerja dan kompetensi dalam aplikasi dilapangan ternyata tidak semua variabel tersebut dapat mempengaruhi kinerja karyawan hal ini terbukti dari beberapa penelitian yang telah dilakukan. Motivasi karyawan tidak serta merta dapat mempengaruhi kinerja seperti beberapa faktor yang telah dijelaskan diatas hal tersebut sejalan dengan hasil penelitian Yuli Suwati (2013) yang menyimpulkan bahwa motivasi kerja secara parsial tidak berpengaruh positif dan signifikan terhadap kinerja karyawan pada PT. Tunas Hijau Samarinda.

Lingkungan kerja sebagai salah satu pendorong seseorang dalam bekerja juga tidak serta merta dapat mempengaruhi kinerja karyawan, hal tersebut sejalan dengan hasil penelitian Trisofia Junita Mamangke, Altje Tumbel danYantje uhing (2015) yang menyimpulkan bahwa lingkungan kerja tidak berpengaruh terhadap kinerja karyawan pada PT. Bangun Wenang Beverages Company Manado.

Begitu juga dengan kompetensi yang merupakan kemampuan yang harus dimiliki oleh karyawan dalam bekerja untuk mencapai target kerja yang telah ditentukan oleh perusahaan atau organisasi ternyata ada yang tidak berpengaruh secara siginifikan terhadap kinerja karyawan sesuai dengan penelitian Rivki Pomalingo, Silva L Mandey dan Yantje Uhing (2015) yang menyimpulkan kompetensi tidak berpengaruh secara signifikan terhadap kinerja.

\subsection{Rumusan Masalah}

Berdasarkan batasan masalah yang telah penulis pilih maka dapat dirumuskan permasalahan penelitian ini sebagai berikut :

1) Apakah motivasi berpengaruh terhadap kinerja karyawan pada PT. Angkasa Pura II (Persero) Kantor Cabang Kualanamu

2) Apakah lingkungan kerja berpengaruh terhadap kinerja karyawan pada PT. Angkasa Pura II (Persero) Kantor Cabang Kualanamu 
3) Apakah kompetensi berpengaruh terhadap kinerja karyawan pada PT. Angkasa Pura II (Persero) Kantor Cabang Kualanamu

4) Apakah motivasi, lingkungan kerja dan kompetensi berpengaruh terhadap kinerja karyawan pada PT. Angkasa Pura II (Persero) Kantor Cabang Kualanamu

\subsection{Batasan Masalah}

Agar penelitian ini lebih fokus, sempurna dan mendalam maka penulis memandang permasalahan penelitian yang diangkat perlu dibatasi sasaran fokus penelitiannya. Oleh sebab itu, penulis membatasi kajiannya hanya berkaitan dengan Pengaruh Motivasi, Lingkungan kerja dan Kompetensi Terhadap Kinerja Karyawan Divisi Electrical And Mechanical Facility PT. Angkasa Pura II Kantor Cabang Kualanamu.

\subsection{Hipotesis}

Berdasarkan batasan dan rumusan permasalahan yang telah dikemukakan sebelumnya, maka hipotesis penelitian ini adalah :

1) Motivasi berpengaruh signifikan secara parsial terhadap kinerja Karyawan PT. Angkasa Pura II (Persero) Kantor Cabang Kualanamu.

2) Lingkungan kerja berpengaruh signifikan secara parsial terhadap Kinerja Karyawan PT. Angkasa Pura II (Persero) Kantor Cabang Kualanamu.

3) Kompetensi berpengaruh signifikan secara parsial terhadap Kinerja Karyawan PT. Angkasa Pura II (Persero) Kantor Cabang Kualanamu.

4) Motivasi, Lingkungan Kerja dan Kompetensi berpengaruh signifikan secara simultan terhadap Kinerja Karyawan PT. Angkasa Pura II (Persero) Kantor Cabang Kualanamu.

\subsection{Tujuan Penelitian}

Berdasarkan rumusan masalah di atas yang telah diuraikan, maka dapat disimpulkan tujuan penelitian yang ada adalah sebagai berikut :

1) Untuk menguji dan menjelaskan pengaruh motivasi terhadap kinerja karyawan pada PT. Angkasa Pura II (Persero) Kantor Cabang Kualanamu?

2) Untuk menguji dan menjelaskan pengaruh lingkungan kerja terhadap kinerja karyawan pada PT. Angkasa Pura II (Persero) Kantor Cabang Kualanamu?
3) Untuk menguji dan menjelaskan pengaruh kompetensi terhadap kinerja karyawan pada PT. Angkasa Pura II (Persero) Kantor Cabang Kualanamu?

4) Untuk menguji dan menjelaskan pengaruh motivasi, lingkungan kerja dan kompetensi terhadap kinerja karyawan pada PT. Angkasa Pura II (Persero) Kantor Cabang Kualanamu?

\section{Metode Penelitian}

\subsection{Populasi}

Menurut Sugiyono (2012:57) "Populasi adalah jumlah keseluruhan unit analisis yang akan diteliti yang mempunyai kuantitas (jumlah) dan karakteristik tertentu yang diterapkan oleh peneliti untuk dipelajari, ada pun yang menjadi kesimpulan bahwa "Populasi penelitian ini adalah karyawan pada PT. Angkasa Pura II (Persero) Kantor Cabang Kualanamu Divisi Electrical and Mechanical Facility berjumlah 54 Orang.

\subsection{Sampel}

Menurut Sugiyono (2012:115) sampel adalah sebagian dari jumlah populasi dan karakteristik yang dimiliki oleh populasi tersebut. Pada penelitian ini, dikarenakan penelitian hanya berfokus pada karyawan Divisi Electrical and Mechanical Facility yang berjumlah sedikit maka sampel pada penelitian ini menggunakan keseluruhan populasi yang ada yaitu 54 orang Karyawan menggunakan sampling jenuh. Menurut Sugiyono (2012:122) sampling jenuh yaitu teknik penetuan sampel bila semua anggota populasi digunakan sebagai sampel.

\subsection{Uji Normalitas}

Uji normalitas untuk melihat apakah dalam model regresi, variabel dependen dan independennya memiliki distribusi normal atau tidak. Jika data menyebar di sekitar garis diagonal dan mengikuti arah garis diagonal maka model regresi memenuhi asumsi normalitas.

Berdasarkan hasil olahan data menggunakan data SPSS versi 22.0 maka di ketahui uji normalitas menggunakan metode PPlot adalah sebagai berikut : 


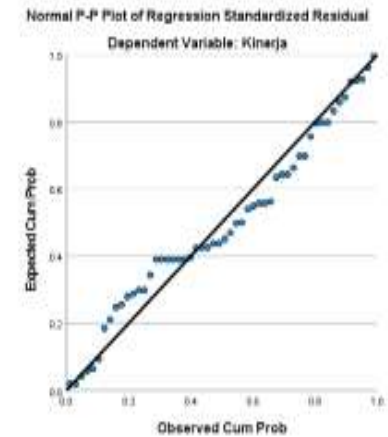

Gambar 1. Uji Normalitas Menggunakan P-Plot diagonal pada gambar, dengan demikian dapat dinyatakan bahwa data telah terdistribusi secara normal.

\subsection{Uji Multikoleniaritas}

Uji Multikoleniaritas bertujuan untuk menguji apakah model regresi ditemukan adanya korelasi yang kuat antara variabel independen dengan melihat nilai VIF (variance inflasi factor) tidak melebihi 10, (Ghozali, 2011, hal. 101).

Gambar tersebut menunjukkan bahwa titiktitik telah membentuk dan mengikuti arah garis

Tabel 1, Coefficients Multikolinieritas

Coefficients $^{\mathbf{a}}$

\begin{tabular}{|c|c|c|c|c|c|c|c|c|}
\hline \multirow{2}{*}{\multicolumn{2}{|c|}{ Model }} & \multicolumn{2}{|c|}{$\begin{array}{c}\text { Unstandardized } \\
\text { Coefficients }\end{array}$} & \multirow{2}{*}{$\begin{array}{c}\text { Standardized } \\
\text { Coefficients }\end{array}$} & \multirow[b]{2}{*}{$\mathrm{T}$} & \multirow[b]{2}{*}{ Sig. } & \multicolumn{2}{|c|}{$\begin{array}{c}\text { Collinearity } \\
\text { Statistics }\end{array}$} \\
\hline & & B & Std. Error & & & & Tolerance & VIF \\
\hline \multirow[t]{4}{*}{1} & (Constant) & -0.109 & 2.799 & & -0.039 & 0.969 & & \\
\hline & Motivasi & 0.179 & 0.091 & 0.197 & 1.960 & 0.056 & 0.346 & 2.892 \\
\hline & $\begin{array}{l}\text { Lingkungan } \\
\text { Kerja }\end{array}$ & 0.151 & 0.073 & 0.185 & 2.076 & 0.043 & 0.440 & 2.273 \\
\hline & Kompetensi & 0.545 & 0.091 & 0.599 & 5.972 & 0.000 & 0.348 & 2.871 \\
\hline
\end{tabular}

a. Dependent Variable: Kinerja

Jika dilihat pada tabel 1 diketahui bahwa variabel motivasi $\left(\mathrm{X}_{1}\right)$, lingkungan kerja $\left(\mathrm{X}_{2}\right)$ dan kompetensi $\left(\mathrm{X}_{3}\right)$ telah mengalami multikolinieritas dimana masing-masing nilai VIF tidak melebihi 10.

\subsection{Uji Heteroskedastisitas}

Uji heteroskedastisitas bertujuan untuk menguji apakah dalam model regresi terjadi ketidaknyamanan vaiance dari residual pengamatan satu ke pengamatan yang lain. Jika variance residual dari suatu pengamatan yang lain tetap maka dikatakan homokedastisitas, dan jika variance berbeda dikatakan heteroskedastisitas. Model yang baik adalah tidak terjadi heteroskedastisitas.

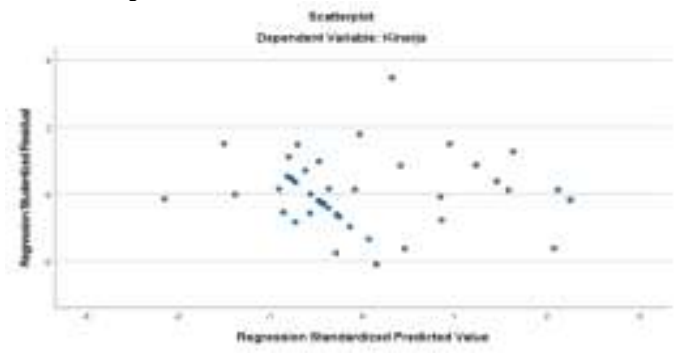

Gambar 2. Uji Heteroskedastisitas Menggunakan Scatterplot
Uji ini akan menyatakan terbebas dari Heteroskedastisitas jika titik-titik yang terdapat pada gambar tersebar secara acak. Gambar di atas menunjukkan suatu pola yang tidak jelas menyebar baik diatas maupun dibawah angka 0 pada sumbu Y.

\section{Hasil Pembahasan \\ 3.1. Regresi Linier Berganda}

Analisis regresi disusun untuk melihat hubungan yang terbangun antara variabel penelitian, apakah hubungan yang terbangun positif atau hubungan negative. Berdasarkan olahan data yang telah dilakukan, maka dapat diketahui bahwa model hubungan dari analisis regresi linier berganda dapat dilihat dari tabel berikut ini : 
Tabel 2. Coefficients Regresi Linier Berganda

Coefficients $^{\mathbf{a}}$

\begin{tabular}{|c|c|c|c|c|c|c|}
\hline & & \multicolumn{2}{|c|}{$\begin{array}{l}\text { Unstandardized } \\
\text { Coefficients }\end{array}$} & \multirow{2}{*}{$\begin{array}{c}\text { Standardized } \\
\text { Coefficients } \\
\text { Beta } \\
\end{array}$} & \multirow[b]{2}{*}{$c$} & \multirow[b]{2}{*}{ Sig. } \\
\hline \multicolumn{2}{|c|}{ Model } & B & Std. Error & & & \\
\hline \multirow[t]{4}{*}{1} & (Constant) & -0.109 & 2.799 & & -0.039 & 0.969 \\
\hline & Motivasi & 0.179 & 0.091 & 0.197 & 1.960 & 0.056 \\
\hline & Lingkungan Kerja & 0.151 & 0.073 & 0.185 & 2.076 & 0.043 \\
\hline & Kompetensi & 0.545 & 0.091 & 0.599 & 5.972 & 0.000 \\
\hline
\end{tabular}

Berdasarkan pada tabel 2 maka dapat disusun model penelitian persamaan regresinya adalah sebagai berikut :

$\mathrm{Y}=-0.109+0,179 \mathrm{X}_{1}+0,151 \mathrm{X}_{2}+0,545 \mathrm{X}_{3}$

Model persamaan regresi berganda tersebut bermakna :

1) Nilai Konstanta sebesar -0.109 yang berarti bahwa jika variabel independen yaitu motivasi $\left(\mathrm{X}_{1}\right)$, lingkungan kerja $\left(\mathrm{X}_{2}\right)$ dan kompetensi $\left(\mathrm{X}_{3}\right)$ sama dengan nol, maka kinerja (Y) adalah sebesar -0.109 .

2) Nilai koefisien regresi $X_{1}=0,179$ menunjukkan apabila kompetensi mengalami kenaikan sebesar 100\% maka akan meningkatkan kinerja karyawan PT. Angkasa Pura II (Persero) Kantor Cabang Kualanamu sebesar $17.9 \%$ kontribusi yang diberikan kompetensi terhadap kinerja karyawan dilihat dari Unstandardized Coefficients pada tabel 4.11 diatas.

3) Nilai koefisien regresi $X_{2}=0,151$ menunjukkan apabila lingkungan kerja mengalami kenaikan sebesar 100\% maka akan mengakibatkan meningkatnya kinerja karyawan PT. Angkasa Pura II (Persero)
Kantor Cabang Kualanamu sebesar $15.1 \%$ kontribusi yang diberikan lingkungan kerja terhadap kinerja karyawan dilihat dari Unstandardized Coefficients pada tabel 4.11 diatas.

4) Nilai koefisien regresi $X_{3}=0,545$ menunjukkan apabila kompetensi mengalami kenaikan sebesar $100 \%$ maka akan mengakibatkan meningkatnya kinerja karyawan PT. Angkasa Pura II (Persero) Kantor Cabang Kualanamu sebesar 54.5\% kontribusi yang diberikan kompetensi terhadap kinerja karyawan dilihat dari Unstandardized Coefficientspada tabel 4.11 diatas.

\subsection{Uji Hipotesis}

\subsubsection{Uji Parsial ( Uji t )}

Uji statistik $t$ dilakukan untuk menguji apakah variabel bebas (X) secara individual mempunyai pengaruh yang signifikan atau tidak terhadap variabel terikat (Y).

\section{1) Pengaruh Motivasi Terhadap Kinerja Karyawan}

Tabel 3. Uji t Variabel Motivasi

\begin{tabular}{|c|c|c|c|c|c|c|}
\hline \multicolumn{7}{|c|}{ Coefficients $^{\mathrm{a}}$} \\
\hline \multirow{2}{*}{\multicolumn{2}{|c|}{ Model }} & \multicolumn{2}{|c|}{ Unstandardized Coefficients } & \multirow{2}{*}{$\begin{array}{c}\begin{array}{c}\text { Standardized } \\
\text { Coefficients }\end{array} \\
\text { Beta } \\
\end{array}$} & \multirow[b]{2}{*}{$\mathrm{T}$} & \multirow[b]{2}{*}{ Sig. } \\
\hline & & B & Std. Error & & & \\
\hline \multirow[t]{2}{*}{1} & (Constant) & -0.109 & 2.799 & & -0.039 & 0.969 \\
\hline & Motivasi & 0.179 & 0.091 & 0.197 & 1.960 & 0.056 \\
\hline
\end{tabular}

Pada tabel di atas dapat di ketahui bahwa variabel $\mathrm{X}_{1}$ yaitu motivasi memiliki signifikansi sebesar 0,056 lebih besar dari 0,05, artinya bahwa motivasi tidak berpengaruh secara signifikan terhadap kinerja karyawan pada PT. Angkasa Pura II (Persero) Kantor Cabang Kualanamu.
Dari tabel 3 tentang pengaruh motivasi $\left(\mathrm{X}_{1}\right)$ terhadap kinerja $(\mathrm{Y})$ diperoleh nilai $\mathrm{t}_{\text {hitung }}$ $1.960<\mathrm{t}_{\text {tabel }} 2.00856$ dengan probabilitas Sig 0,056 , lebih besar dari $\alpha=0,05$. Dapat di simpulkan bahwa motivasi $\left(\mathrm{X}_{1}\right)$ secara parsial tidak mempunyai pengaruh signifikan terhadap kinerja (Y) pada Divisi Electrical and 
Mechanical Facility PT. Angkasa Pura II kriteria pengujian hipotesis sebagai berikut: (Persero) Kantor Cabang Kualanamu. Dengan

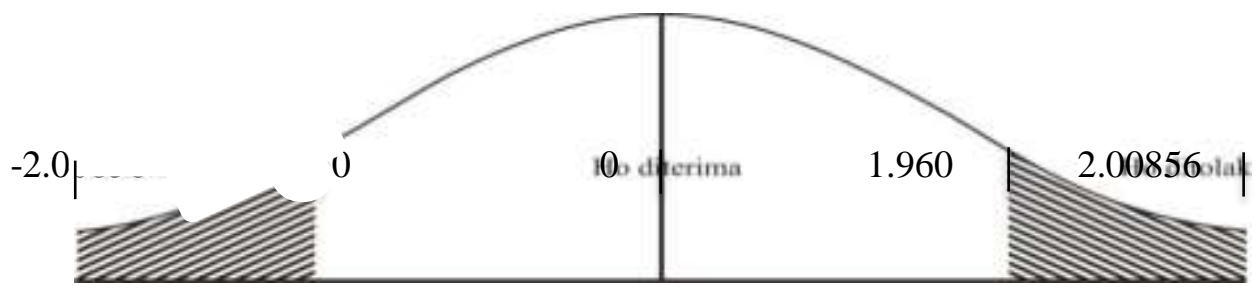

Gambar 3. Pengaruh Motivasi Terhadap Kinerja

\section{2) Pengaruh Lingkungan Kerja Terhadap Kinerja Karyawan}

Tabel 4. Uji t Variabel Lingkungan Kerja

\begin{tabular}{|c|c|c|c|c|c|c|}
\hline \multicolumn{7}{|c|}{ Coefficients $^{\mathbf{a}}$} \\
\hline \multirow{2}{*}{\multicolumn{2}{|c|}{ Model }} & Unstandardize & Coefficients & $\begin{array}{l}\text { Standardized } \\
\text { Coefficients }\end{array}$ & & \\
\hline & & B & Std. Error & Beta & $\mathrm{T}$ & Sig. \\
\hline & $\begin{array}{l}\text { Lingkunga } \\
\mathrm{n} \text { Kerja }\end{array}$ & 0.151 & 0.073 & 0.185 & 2.076 & 0.043 \\
\hline
\end{tabular}

Pada tabel 4. di atas dapat diketahui bahwa variabel $\mathrm{X}_{2}$ yaitu lingkungan kerja memiliki signifikan sebesar 0,043 lebih kecil dari 0,05 artinya bahwa lingkungan kerja berpengaruh signifikan terhadap kinerja karyawan pada PT. Angkasa Pura II (Persero) Kantor Cabang Kualanamu.

Dari tabel 4. tentang pengaruh lingkungan kerja $\left(\mathrm{X}_{2}\right)$ terhadap kinerja $(\mathrm{Y})$ diperoleh nilai $\mathrm{t}_{\text {hitung }} 2.076>\mathrm{t}_{\text {tabel }} 2.00856$ dengan probabilitas Sig 0,043, lebih kecil dari $\alpha=0,05$. Dapat di simpulkan bahwa lingkungan kerja $\left(\mathrm{X}_{2}\right)$ secara parsial berpengaruh signifikan terhadap kinerja (Y) Divisi Electrical and Mechanical Facility PT. Angkasa Pura II (Persero) Kantor Cabang Kualanamu. Dengan kriteria pengujian hipotesis sebagai berikut :

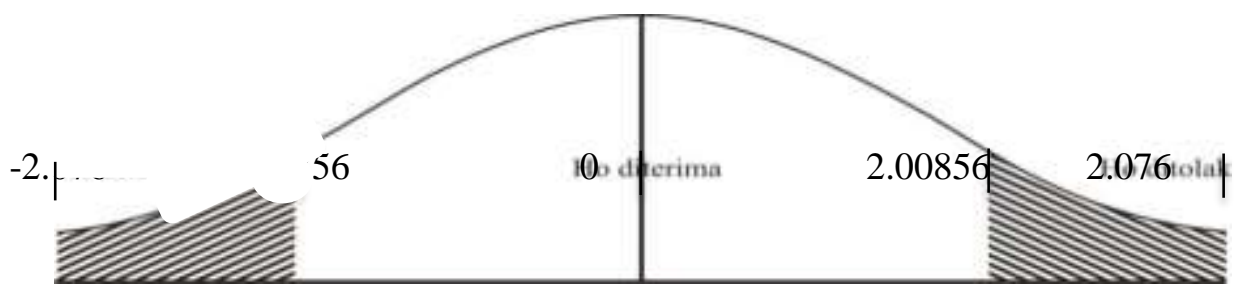

Gambar 4. Pengaruh Lingkungan Kerja Terhadap Kinerja

\section{3) Pengaruh Kompetensi Terhadap Kinerja Karyawan}

Tabel 5. Uji t Variabel Kompetensi

\begin{tabular}{|c|c|c|c|c|c|}
\hline \multicolumn{6}{|c|}{ Coefficients $^{\mathrm{a}}$} \\
\hline \multirow[b]{2}{*}{ Model } & \multicolumn{2}{|c|}{ Unstandardized Coefficients } & $\begin{array}{l}\text { Standardized } \\
\text { Coefficients }\end{array}$ & \multirow[b]{2}{*}{$\mathrm{T}$} & \multirow[b]{2}{*}{ Sig. } \\
\hline & B & Std. Error & Beta & & \\
\hline $\begin{array}{l}\text { Kompetens } \\
\mathrm{i}\end{array}$ & 0.545 & 0.091 & 0.599 & 5.972 & 0.000 \\
\hline
\end{tabular}

Pada tabel 5. di atas dapat diketahui bahwa variabel $\mathrm{X}_{3}$ yaitu kompetensi memiliki signifikan sebesar 0,000 lebih kecil dari 0,05, artinya bahwa kompetensi berpengaruh signifikan terhadap kinerja karyawan pada Divisi Electrical and Mechanical Facility PT. Angkasa Pura II (Persero) Kantor Cabang Kualanamu. 
Dari tabel 5. tentang pengaruh kompetensi $\left(\mathrm{X}_{3}\right)$ terhadap kinerja $(\mathrm{Y})$ diperoleh nilai $\mathrm{t}_{\text {hitung }}$ $5.972>\mathrm{t}_{\text {tabel }} 2.00856$ dengan probabilitas Sig 0,000 , lebih kecil dari $\alpha=0,05$. Dapat di simpulkan bahwa pola kompetensi $\left(\mathrm{X}_{3}\right)$ secara parsial mempunyai pengaruh signifikan terhadap kinerja (Y) pada PT. Angkasa Pura II (Persero) Kantor Cabang Kualanamu. Dengan kriteria pengujian hipotesis sebagai berikut :

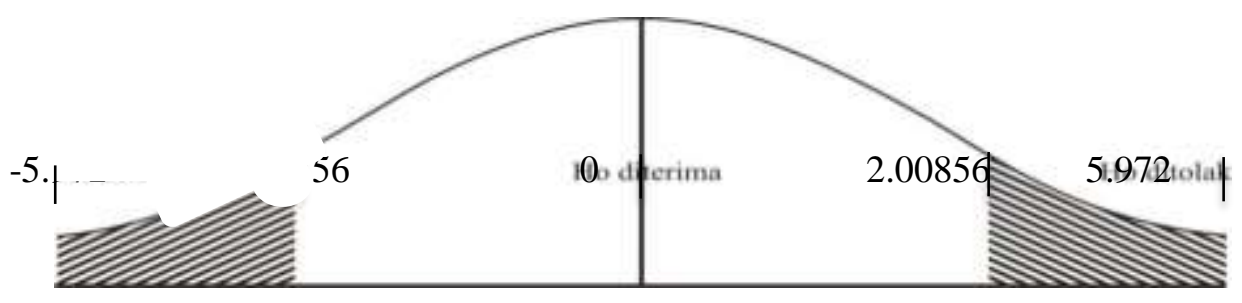

Gambar 5. Pengaruh Kompetensi Terhadap Kinerja

\subsubsection{Uji Simultan ( Uji F )}

Uji statistik F (simultan) dilakukan untuk mengetahui apakah variabel bebas (independent) secara bersama-sama berpengaruh secara signifikan atau tidak terhadap variabel terikat (dependen). Hasil uji secara simultan dapat dilihat dari tabel dibawah ini :

\begin{tabular}{|c|c|c|c|c|c|}
\hline \multicolumn{6}{|c|}{$\begin{array}{l}\text { Tabel 6. Uji F } \\
\text { ANOVA }^{\mathbf{a}}\end{array}$} \\
\hline Model & $\begin{array}{l}\text { Sum of } \\
\text { Squares }\end{array}$ & df & Mean Square & $\mathrm{F}$ & Sig. \\
\hline 1 Regression & 708.175 & 3 & 236.058 & 78.342 &, $000^{\mathrm{b}}$ \\
\hline Residual & 150.659 & 50 & 3.013 & & \\
\hline Total & 858.833 & 53 & & & \\
\hline
\end{tabular}

Berdasarkan dari tabel uji $\mathrm{F}$ diketahui bahwa terdapat nilai signifikan sebesar 0,000 nilai signifikan ini lebih kecil dari 0,05 artinya bahwa motivasi, lingkungan kerja dan kompetensi berpengaruh signifikan terhadap kinerja karyawan pada Divisi Electrical and Mechanical Facility PT. Angkasa Pura II (Persero) Kantor Cabang Kualanamu.
Jika dibandingkan nilai $\mathrm{F}_{\text {hitung }}$ dengan $\mathrm{F}_{\text {tabel }}$ maka dihasilkan $78.342>2.79$ sehingga di simpulkan bahwa motivasi, lingkungan kerja dan kompetensi berpengaruh signifikaan terhadap kinerja karyawan pada PT. Angkasa Pura II (Persero) Kantor Cabang Kualanamu.

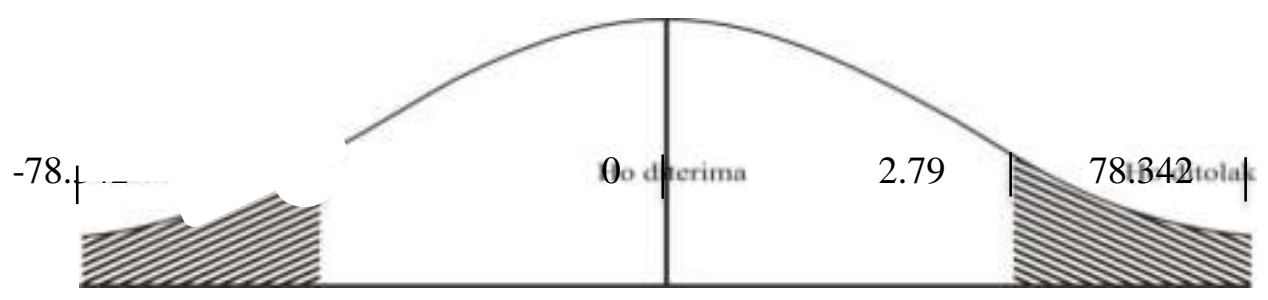

Gambar 6. Pengaruh Kompensasi, Analisis Jabatan dan Pola Pengembangan Karir Terhadap Kinerja

\subsubsection{Koefisien Determinasi}

Uji determinasi ini untuk melihat seberapa besar motivasi, lingkungan kerja dan kompetensi dalam menjelaskan variasi variabel dependen yaitu kinerja. Untuk mengetahui besarnya determinasi motivasi, lingkungan kerja dan kompetensi, dan pola pengembangan karir dalam menjelaskan variasi variabel dependennya yaitu kinerja dapat dilihat pada tabel berikut ini : 
Tabel 7. Koefisien Determinasi (R-Square)

\begin{tabular}{|c|c|c|c|c|}
\hline & 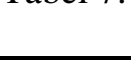 & Mod & Summary & \\
\hline Model & $\mathrm{R}$ & R Square & $\begin{array}{l}\text { Adjusted R } \\
\text { Square }\end{array}$ & $\begin{array}{l}\text { Std. Error of the } \\
\text { Estimate }\end{array}$ \\
\hline 1 & ,908 & ,825 & ,814 & 1.736 \\
\hline
\end{tabular}

Berdasarkan pada tabel di atas diketahui bahwa nilai $\mathrm{R}_{\text {square }}$ adalah sebesar 0,825 atau sama dengan $82.5 \%$ artinya bahwa motivasi, lingkungan kerja dan kompetensi mampu untuk menjelaskan kinerja karyawan Divisi Electrical and Mechanical Facility PT. Angkasa Pura II (Persero) Kantor Cabang Kualanamu adalah sebesar $82.5 \%$ dan sisanya $17.5 \%$ dijelaskan oleh variabel bebas yang lainnya yang tidak diikutsertakan ke dalam model penelitian ini.

\section{Pembahasan}

Dari hasil pengujian terlihat bahwa semua variabel bebas motivasi $\left(\mathrm{X}_{1}\right)$, lingkungan kerja $\left(\mathrm{X}_{2}\right)$ dan kompetensi $\left(\mathrm{X}_{3}\right)$ mempunyai pengaruh terhadap variabel kinerja (Y) untuk lebih memperjelas terhadap rincian hasil analisis dan pengujian tersebut dapat di jelaskan sebagai berikut :

\subsection{Pengaruh Motivasi Terhadap Kinerja Karyawan}

Setiap karyawan yang bekerja harus memiliki motivasi baik dalam membangkitkan, mengarahkan dan menjaga perilaku dalam bekerja sehingga tujuan perusahaan akan tercapai. Oleh karena itu perusahaan harus memperhatikan motivasi karyawan dalam menjalankan usahanya.

Mc. Donald dalam Sardiman A.M. (2011:73) mengemukakan bahwa motivasi adalah perubahan energi dalam diri seseorang yang ditandai dengan munculnya feeling dan didahului dengan tanggapan terhadap adanya tujuan. Untuk menjaga motivasi karyawan dalam bekerja perusahan harus terus menerus memberikan motivasi terhadap karyawan, contohnya yaitu memberikan reward atas prestasi kerjanya, kemudian memberikan kompensasi berupa tunjangan fasilitas dalam bekerja apabila karyawan tersebut dapat melebihi target yang telah ditetapkan perusahaan, atau dengan memberikan ucapan terima kasih atas kinerja yang mereka lakukan. Dengan memberikan hal tersebut diatas diharapkan dapat mempengaruhi kinerja karyawan.
Namun dari hasil penelitian ini menyatakan bahwa tidak adanya pengaruh antara motivasi terhadap kinerja karyawan. Berdasarkan hasil penelitian mengenai pengaruh antara motivasi terhadap kinerja karyawan pada Divisi Electrical and Mechanical Facility PT. Angkasa Pura II (Persero) Kantor Cabang Kualanamu yang menyatakan $\mathrm{t}_{\text {hitung }}<\mathrm{t}_{\text {tabel }}$ yaitu $1.960 \leq 2.00665$ berada di daerah penerimaan $\mathrm{H} 0$ sehingga $\mathrm{Ha}$ ditolak, hal ini dinyatakan bahwa motivasi tidak berpengaruh signifikan secara parsial terhadap kinerja karyawan di PT. Angkasa Pura II (Persero) Kantor Cabang Kualanamu. Menurut Sutrisno (2009:116) ada beberapa faktor yang mempengaruhi motivasi seseorang salah satunya yaitu kompensasi yang memadai. Berdasarkan hasil kerja/ usaha PT Angkasa Pura II (Persero) tahun 2020 dalam mencari keuntungan mendapati suatu kendala yang sangat besar yaitu telah terjadi pandemic Covid 19 di seluruh dunia dan berimbas ke Negara Republik Indonesia yang mengakibatkan berkurangnya masyarakat bepergian dengan menggunakan alat transportasi udara. Dengan sedikitnya masyarakat menggunakan pesawat untuk bepergian mengakibatkan berkurangnya pendapatan perusahaan. Untuk mengoptimal kinerja perusahaan maka PT Angkasa Pura II (Persero) melakukan langkah-langkah strategis guna perusahaan dapat survive (selamat) salah satunya mengurangi kompensasi yaitu berupa tunjangan bonus yang harus diberikan tiap tahun kepada seluruh karyawan. Dengan berkurangnya kompensasi yang diberikan perusahaan sehingga menyebabkan turunnya motivasi dalam bekerja. Langkah strategis yang diambil perusahaan ini sangat dirasakan oleh karyawan dimana kompensi ini sudah biasa mereka terima setiap tahun. Hal ini merupakan salah satu yang menyebabkan motivasi kerja karyawan pada unit Divisi Electrical and Mechanical Facility menjadi turun.

Hasil penelitian ini sejalan dengan hasil penelitian terdahulu. Sesuai dengan hasil penelitian Indra Marjaya dan Fajar Pasaribu 
(2019) menyimpulkan bahwa motivasi tidak berpengaruh secara signifikan terhadap kinerja. Berdasarkan hasil penelitian diatas perlu adanya evaluasi secara internal terkait dengan motivasi pada setiap karyawan Divisi Electrical and Mechanical Facility PT. Angkasa Pura II (Persero) Kantor Cabang Kualanamu

\subsection{Pengaruh Lingkungan Kerja terhadap Kinerja Karyawan}

Lingkungan kerja menjadi salah satu hal yang memengaruhi produktivitas dan semangat kerja karyawan. Tanpa lingkungan kerja yang baik, karyawan akan mudah bosan dan tidak betah untuk bekerja di tempat tersebut. Untuk menciptakan rasa aman dan nyaman dalam bekerja perlunya perusahaan menyediakan hal tersebut sehingga kinerja karyawan menjadi meningkat. Menurut Lewa dan Subono (2005:235) bahwa lingkungan kerja didesain sedemikian rupa agar dapat tercipta hubungan kerja yang mengikat pekerja dengan lingkungan. Lingkungan kerja yang menyenangkan dapat membuat para karyawan merasa betah dalam menyelesaikan pekerjaannya serta mampu mencapai suatu hasil yang optimal. Sebaliknya apabila kondisi lingkungan kerjatersebut tidak memadai menimbulkan dampak negatif dalam penurunan tingkat produktifitas kinerja karyawan.

Hasil penelitian ini menyatakan bahwa ada pengaruh antara lingkungan kerja terhadap kinerja. Berdasarkan hasil penelitian mengenai pengaruh antara lingkungan kerja terhadap kinerja karyawan pada PT. Angkasa Pura II (Persero) Kantor Cabang Kualanamu yang menyatakan $t_{\text {hitung }}>t_{\text {tabel }}$ yaitu $2.076>2.00856$ berada di daerah penerimaan $\mathrm{H} 1$ sehingga $\mathrm{H} 0$ ditolak, hal ini di nyatakan bahwa lingkungan kerja berpengaruh signifikan secara parsial terhadap kinerja karyawan di Divisi Electrical and Mechanical Facility PT. Angkasa Pura II (Persero) Kantor Cabang Kualanamu.

Hal ini sejalan dengan hasil jurnal penelitian terdahulu Zainul Hidayat, MM \& Muchamad Taufig, MH (2012) yang menunjukkan bahwa lingkungan kerja berpengaruh terhadap kinerja. Hasil Jurnal penelitian Susanto dan Idhan Halim (2020) juga menyatakan bahwa lingkungan kerja berpengaruh terhadap kinerja karyawan. Diharapkan dengan tersedianya lingkungan kerja yang baik dan optimal, para karyawan dapat meningkatkan aktualisasi diri dan meningkatkan kinerjanya.

\subsection{Pengaruh Kompetensi terhadap Kinerja Karyawan}

Kompetensi yang merupakan salah satu syarat dalam mengembangkan perusahaan harus terus diberikan kepada karyawan, dikarenakan hal ini merupakan tuntutan dalam persaingan global. Perusahaan yang tidak mampu mengikuti perkembangan jaman pada saat ini akan tertinggal dan mungkin saja tidak dapat berjalan lagi atau bangkrut.

Wibowo (2011:324) mendefinisikan kompetensi sebagai kemampuan untuk melaksanakan atau melakukan suatu pekerjaan atau tugas yang dilandasi atas keterampilan dan pengetahuan, serta didukung oleh sikap kerja yang dituntut oleh bercirikan profesionalisme dalam suatu bidang tertentu sebagai sesuatu yang penting atau sebagai sebuah unggulan. Kompetensi juga merupakan kemampuan seseorang untuk menghasilkan tingkat yang memuaskan di tempat kerja, mentransfer dan mengaplikasikan keterampilan dan pengetahuannya dalam situasi yang baru, serta meningkatkan manfaat yang disepakati.

Hasil penelitian ini menyatakan bahwa ada pengaruh antara kompetensi terhadap kinerja. Berdasarkan hasil penelitian mengenai pengaruh antara kompetensi terhadap kinerja pada karyawan Divisi Electrical and Mechanical Facility PT. Angkasa Pura II (Persero) Kantor Cabang Kualanamu yang menyatakan $\mathrm{t}_{\text {hitung }}>\mathrm{t}_{\text {tabel }}$ yaitu $5.972>2.00856$ berada di daerah penerimaan $\mathrm{H} 1$ sehingga $\mathrm{H} 0$ ditolak, hal ini dinyatakan bahwa kompetensi berpengaruh signifikan secara parsial terhadap kinerja karyawan di Divisi Electrical and Mechanical Facility PT. Angkasa Pura II (Persero) Kantor Cabang Kualanamu. Hal ini sejalan dengan hasil penelitian terdahulu Edi Hermawan (2019) yang menunjukkan bahwa kompetensi berpengaruh secara signifikan terhadap kinerja. Hasil penelitian Hamlan Daly (2015) juga menyatakan bahwa kompetensi berpengaruh terhadap kinerja karyawan.

\subsection{Pengaruh Motivasi, Lingkungan Kerja dan Kompetensi terhadap Kinerja Karyawan}

Banyak unsur-unsur yang dapat menentukan naik turunnya kinerja karyawan di setiap perusahaan. Unsur-unsur tersebut harus selalu diperhatikan oleh perusahaan agar tujuan dari perusahaan dapat terwujud. Sudah pasti setiap perusahaan menginginkan kegiatan 
operasionalnya berjalan dengan baik dan mendapatkan hasil atau keuntungan yang meningkat setiap tahun berjalan. Unsur-unsur tersebut diantaranya adalah motivasi yang tinggi, lingkungan kerja yang optimal dan kompetensi yang memadai yang dimiliki karyawan.

Menurut Andersen dalam Sudarmanto (2018:7) menyatakan bahwa paradigma produktivitas yang baru adalah paradigma kinerja secara actual yang menuntut pengukuran secara aktual keseluruhan kinerja organisasi, tidak hanya efisiensi atau dimensi fisik, tetapi juga dimensi non fisik. Motivasi yang tinggi, lingkungan kerja yang optimal dan kompetensi yang memadai yang dimiliki karyawan sangat mempengaruhi kinerja karyawan. Hal diatas diharapkan akan membentuk seorang karyawan profesional.

Hasil penelitian ini menyatakan bahwa ada pengaruh secara simultan antara motivasi, lingkungan kerja dan kompetensi terhadap kinerja. Berdasarkan hasil penelitian mengenai pengaruh antara motivasi, lingkungan kerja dan kompetensi terhadap kinerja karyawan di PT. Angkasa Pura II (Persero) Kantor Cabang Kualanamu pada penelitian ini sudah jelas terbukti ada pengaruh secara simultan, di mana hasil uji $\mathrm{F}$ di dapat nilai $\mathrm{F}_{\text {hitung }} \geq \mathrm{F}_{\text {tabel }}$ yaitu $78.342 \geq 2.9$ dengan signifikan $0,000<0,05$. Karena $\mathrm{F}_{\text {hitung }}$ lebih besar dari $\mathrm{F}_{\text {tabel }}$ maka $\mathrm{HO}$ di tolak dan $\mathrm{Ha}$ di terima artinya ada pengaruh antara motivasi, lingkungan kerja dan kompetensi terhadap kinerja karyawan di Divisi Electrical and Mechanical Facility PT. Angkasa Pura II (Persero) Kantor Cabang Kualanamu. Hal ini sejalan dengan hasil penelitian terdahulu Bukhar, Sjahril Effendi Pasaribu (2019) yang menunjukkan bahwa motivasi, kompetensi dan lingkungan kerja berpengaruh terhadap kinerja. Pernyataan di atas didukung juga oleh hasil penelitian Nurul Azmi, Serlin Serang (2019) yang menyimpulkan bahwa motivasi, kompetensi dan lingkungan kerja berpengaruh terhadap kinerja.

\section{Kesimpulan}

Berdasarkan hasil penelitian dan pembahasan yang dilakukan oleh peneliti mengenai pengaruh motivasi, lingkungan kerja dan kompetensi terhadap kinerja karyawan dari Divisi Electrical and Mechanical Facility di PT. Angkasa Pura II (Persero) Kantor Cabang
Kualanamu, maka dapat ditarik kesimpulan sebagai berikut :

1) Motivasi secara parsial tidak berpengaruh signifikan terhadap kinerja.

2) Lingkungan kerja secara parsial berpengaruh signifikan terhadap kinerja.

3) Kompetensi secara parsial berpengaruh signifikan terhadap kinerja.

4) Motivasi, lingkungan kerja dan kompetensi secara simultan berpengaruh signifikan terhadap kinerja.

\section{DAFTAR PUSTAKA}

A.M. Sardiman. 2007. Interaksi Dan Motivasi Belajar Mengajar. Bandung: Rajawali Pers.

Anwar Prabu Mangkunegara. 2006. Evaluasi Kinerja Sumber Daya Manusia. Jakarta Refika Aditama.

AM. Sardiman. 2011. Interaksi dan Motivasi Belajar Mengajar. Jakarta : Rajawali Press.

Ashar Sunyoto Munandar, 2001, Psikologi Industri dan Organisasi, Universitas Indonesia (UI-Press), Jakarta.

Bernadin, H John \& Joyce E. A. Russel. 2001. Human Resource Management Singapura: Mc Graw-Hill Inc.

Dessler, Gary. 2009. Manajemen Sumber Daya Manusia. (Jilid Dua, Edisi ke-10). Jakarta: PT Indeks.

Edy, Sutrisno. 2011. Manajemen Sumber Daya Manusia. Jakarta: Kencana.

Gie, The Liang. 2000. Administrasi Perkantoran Modern. Yogyakarta. Liberty.

Greenberg, J. And Robert A. Baron. 2003. Behavior in Organization International Edition, New Jersey: Prentice Hall.

Handoko, T. Hani. 2003. Manajemen Personalia Dan Sumber Daya Manusia. Edisi Kedua. Cetakan Kelima. Yogyakarta: BPFE.

Hasibuan, Melayu S.P 2007. Manjemen Sumber Daya Manusia Perusahaan, Bandung, PT . Bumi Aksa

Hasibuan, Malayu. S.P. 2003. Manajemen Sumber Daya Manusia, Jakarta: PT. Bumi Aksara.

Hasibuan, Malayu. S.P. 2006. Organisasi dan Motivasi - Dasar Peningkatan Produktivitas. Jakarta: PT. Bumi Aksara

Hasibuan, Malayu. S.P. 2007. Manajemen Sumber Daya Manusia. Jakarta: PT. Bumi Aksara.

Hutapea, Parulian dan Nurianna Thoha. 2008. Kompetensi Plus. Jakarta: PT. Gramedia Pustaka Utama. 
Ivancevich, John M, Konopaske Robert \& Matteson Michael T 2007, Perilaku Dan Manajemen Organisasi (Alih Bahasa Gina Gania), Edisi Tujuh, Erlangga, Jakarta

Kadarisman. 2012. Manajemen Pengembangan Sumber Daya Manusia. Jakarta: PT Raja Grafindo Persada.

Luthans, Fred. 2005. Organizational Behavior. ( $7^{\text {th }}$ ed). New York: McGraw-Hill Inc.

Lewa, S. 2005. Perilaku dan Budaya Organisasi. Bandung : PT. Refika Aditama.

Mangkunegara, A.A. Anwar Prabu. 2006. Evaluasi Kinerja Sumber Daya Manusia. Bandung: PT. Refika Aditema.

Mangkunegara, A.A. Anwar Prabu. 2005. Manajemen Sumber Daya Manusia Perusahaan. Bandung: PT. Remaja Rosdakarya.

Mangkunegara, 2013. Manajemen Sumber Daya Manusia Perusahaan, Remaja Rosdakarya, Bandung.

Mangkunegara, A.A. Anwar Prabu (2017). Manajemen Sumber Daya Manusia Perusahan. Bandung : Rosda

Mardiana. 2005. Manajemen Produksi. Jakarta: Penerbit Badan Penerbit IPWI.

Mathis, Robert L dan John H. Jackson. 2009. Manajemen Sumber Daya Manusia: Buku Dua. Jakarta: Salemba Empat.

Moeheriono. 2012. Pengukuran Kinerja Berbasis Kompetensi. Jakarta: Raja Grafindo Persada.

Moekijat. 2002. Manajemen Tenaga Kerja Dan Hubungan Kerja. Bandung: Pionir Jaya.

Ngalim Purwanto. 2006. Psikologi Pendidikan. Bandung : PT. Remaja.

Nitisemito, Alex 1996. Manajemen Personalia (Manajemen Sumber Daya Manusia). Jakarta: Ghalia.

Rampersad, Hubert K. 2006. Total Performance Scorecard. Jakarta: Gramedia Pustaka Utama.

Rivai, Veithzal. 2004. Manajemen Sumber Daya Manusia Untuk Perusahaan. Jakarta: Raja Grafindo Persada.

Rivai, Veithzal. 2005. Manajemen Sumber Daya Manusia Untuk Perusahaan : Dari Teori Ke Praktek. Jakarta: PT. Raja Grafindo Persada.

Rivai, Veithzal. 2013. Manajemen Sumber Daya Manusia Untuk Perusahaan, (Cetakan Pertama). Jakarta: Raja Grafindo Persada.

Robbins, Stephen P. 2002. Perilaku Organisasi. Jakarta: Erlangga.
Robbins, Stephen P., Timothy A. Judge. 2008. Perilaku Organisasi. Terjemahan oleh Diana Angelica. (Buku 1, Edisi 12). Jakarta: Penerbit Salemba Empat.

Robert L. Mathis dan John H. Jackson. 2009. Human Resource Management. Terjemahan oleh Diana Angelica. (Edisi ke-10). Jakarta: Penerbit Salemba Empat.

Ruky, Achmad S. 2006. Sistem Manajemen Kinerja. Jakarta: PT. Bumi Aksara.

Saydam, Gouzali. 2000. Manajemen Sumber Daya Manusia (Human Resources Management) Suatu Pendekatan Mikro. Cetakan Kedua. Jakarta: Djambatan.

Sarwono, S. W. 2005. Psikologi Lingkungan. Jakarta: PT Gramedia Grasindo.

Sedarmayanti. 2009. Sumber Daya Manusia dan Produktivitas Kerja. Bandung: CV. Mandar Maju.

Sedarmayanti. 2017. Perencana dan Pengembangan Sumber Daya Manusia. Bandung: PT Refika Aditama.

Siagian, Sondang P. 2004. Manajemen Sumber Daya Manusia. Jakarta: Bumi Aksara.

Spencer, Lyle \& signe M. Spencer. 1993. Competence at Work, Models for Superior Performance. Canada: John Wiley \& Sons, Inc.

Sukanto dan Indriyo. 2000. Manajemen Personalia. Jakarta: Erlangga.

Sutrisno, Edi. 2009. Manajemen Sumber Daya Manusia. Edisi petama, Jakarta: Kencana Prenada Media Grup.

Sutrisno, Edi. 2014. Manajemen Sumber Daya Manusia. Jakarta: Kencana.

Simanjuntak, Payaman J. 2005. Manajemen dan Evaluasi Kinerja. Jakarta: FE UI.

Soekarno dan Indriyo, 2000. Lingkungan Kerja. Jakarta: Bina Aksara.

Stoner, James A.F. 2004. Manajemen. (Edisi Kelima, Cetakan Pertama). Jakarta: Penerbit Intermedia.

Sudarmanto (2018). Kinerja dan Pengembangan Komptensi SDM. Yogyakarta: Pustaka Pelajar.

Wibowo. 2007. Manajemen Kinerja. Jakarta: PT. Raja Grafindo Persada.

Wibowo. 2011. Manajemen Kinerja. (Edisi Ketiga). Jakarta: PT. Raja Grafindo Persada.

Wibowo. 2013. Manajemen Kinerja. Jakarta: Rajawali Pers.

Wibowo. 2014. Manajemen Kinerja. (Edisi Keempat). Jakarta: Rajawali Pers. 
Zwell, Michael. 2000. Creating A Culture of Competence. New York: John Wiley \& Sons, Inc.

\section{Jurnal.}

Aji Tri Budianto dan Amelia Katini. 2015. Pengaruh Lingkungan Kinerja Terhadap Kinerja Pegawai Pada PT. Perusahaan Gas Negara (Persero) Tbk SBU Distribusi Wilayah I Jakarta. Jurnal Manajemen Universitas Pamulang. Vol. 3 no. 1, Oktober 2015.

Akhmad Fauzi. 2018. Pengaruh Kompetensi Terhadap Kinerja Pegawai Pada Biro Pemerintahan Dan Kerjasama Sekretariat Daerah Provinsi Jawa Barat. Jurnal Administrasi Dan Kebijakan Publik Universitas Pasundan Bandung.

Andi Irwan. 2006. Pengaruh Kompetensi Terhadap kinerja Pegawai Pada Dinas Pendidikan, Kebudayaan, Pemuda dan Olahraga Kabupaten Mamuju Utara. Jurnal Universitas Tadulako Palu.

Angela Worang dan Roy F. Runtuwene. 2019. Pengaruh Motivasi Dan Disiplin Kerja Terhadap Kinerja Kerja PDAM Kota Tomohon. Jurnal Administrasi Bisnis Universitas Sam Ratulangi Manado. Vol. 8 No. 2.

Ary Sutrischastini dan Agus Riyanto. 2015. Pengaruh Motivasi Kerja Terhadap Kinerja Pegawai Kantor Sekretariat Daerah Kabupaten Gunungkidul. Jurnal Manajemen Widya Wiwaha Yogyakarta. Vol 23 no. 2.

Bukhari dan Sjahril Effendi Pasaribu. 2019. Pengaruh Motivasi, Kompetensi, Dan Lingkungan Kerja Terhadap Kinerja. Jurnal Manajemen Muhammadiyah Sumatera Utara. Vol. 2 no. 1, Maret 2019.

Diana Khairani Sofyan. 2013. Pengaruh Lingkungan Kerja Terhadap Kinerja Kerja Pegawai BAPPEDA. Jurnal Teknik Industri Malikusaleh Lhokseumawe Aceh. Vol. 2 No. 1.

Kerka, S. 1998. Competency-Based Education and Training : Myths and Realities. ERIC / ACVE. Retrieved July 1, 2003, from http:// ericacve.org/deogen.asp? tbl $=m r \& I D=65$, Presently Available at http://www.erc.ed.gov/.

Kiki Cahaya Setiawan 2015. Pengaruh motivasi kerja terhadap kinerja karyawan level pelaksana di divisi operasi PT. Pusri Palembang. Jurnal Psikologi Islami Palembang 2015.
Marliana Budhiningtias Winanti 2011. Pengaruh Kompetensi Terhadap Kinerja Karyawan (survei pada PT. Frisian Flag Indonesia Wilayah Jawa Barat). Jurnal Program studi manajemen informatika. Jawa Barat.

Namira Mardin Amin. 2015. Pengaruh Kompetensi Terhadap Kinerja Pegawai Di Sekretariat Daerah Kabupaten Sidenreng Rappang. Jurnal Administrasi Negara Universitas Hasanuddin.

Usri Nani Yunarifah dan Lilik Kustiani. 2012. Pengaruh Motivasi Kerja Terhadap Kinerja Karyawan PT. Kebon Agung Malang. Jurnal Ekonomi Modernisasi. Vol. 8 no. 2. Juni 2012. 